physical research, other branches of study will be represented, including photography, medical physics, civil and mechanical engineering and chemistry. The exhibition is under the patronage of the Cultural and Commercial Counsellors to the French Embassy. During the course of the exhibition a number of public lectures by French men of science will be given, details of which will be announced shortly. The exhibition will be open to the public without charge during February 9-26 (weekdays, 10 a.m.-6 p.m.; Sundays, 2.30-6 p.m.). A comprehensive catalogue of some 100 pages will be on sale at the Museum, and representatives of the participating bodies will be present throughout to assist visitors with additional technical information.

\section{Physical Society's Annual Exhibition}

The thirty-fourth annual Exhibition of Scientific Instruments and Apparatus arranged by the Physical Society will be held during March 31-April 5 inclusive at the Imperial College of Science and Technology, Imperial Institute Road, London, S.W.7. The Exhibition will be open on March 31, April 3 and April 4 from 10 a.m. to 1 p.m. and from 2 p.m. to 9 p.m., and on April 1 and April 5 from 10 a.m. to 1 p.m. and from 2 p.m. to 5 p.m. The morning session on March 31 is for fellows of the Society and the Press only. It will be noted that the Exhibition is to remain open for a longer period than in previous years. Invitations to exhibit have been accepted by firms, research associations, universities and government departments as in the past, and the handbook of the Exhibition containing descriptions of all items to be displayed will be available from the SecretaryEditor, Physical Society, I Lowther Gardens, Prince Consort Road, London, S.W.7, at the beginning of March, price 6s. post paid. During the Exhibition, discourses will be given by Prof. S. Chapman, Dr. W. D. Wright, Dr. F. J. Scrase and Sir Robert Watson-Watt. The Craftsmanship and Draughtsmanship Competition for Apprentices and Leamers is again being held, and some of the entries will be on view at the Exhibition.

\section{Zoological Society of India: 1949 Elections}

Foundation fellows of the Zoological Society of India, who were elected in 1949, are as follows : Dewan Anand Kumar (Solan), Dr. A. A. Ayer (Madras), Dr. K. N. Bahl (Lucknow), Dr. D. V. Bal (Bombay), Dr. J. L. Bhaduri (Calcutta), Dr. D. R. Bhattacharya (Allahabad), Dr. B. S. Bhimachar (Calicut), Dr. B. S. Chanhan (Calcutta), Dr. B. N. Chopra (New Delhi), Dr. B. K. Das (Hyderabad), Mr. M. N. Datta (Calcutta), Prof. R. Gopala Aiyer (Waltair), Dr. S. L. Hora (Calcutta), Dr. M. O. T. Iyengar (Calcutta), Dr. T. S. Job (Barrackpore), Dr. G. L. Kestiven (Singapore), Dr. K. B. Lal (Kaupur), Dr. M. S. Mani (Agra), Prof. H. R. Mehra (Allahabad), Prof. M. B. Mirza (Aligarh), Prof. A. B. Misra (Benares), Dr. K. S. Misra (Calcutta), Prof. M. A. Moghe (Nagpur), Dr. K. B. Nair (Trivandrum), Dr. N. K. Paniklkar (Mandapani), Dr. H. S. Pruthi (New Delhi), Dr. L. S. Ramaswami (Bangalore), Dr. H. S. Rao (Mandapani), Dr. H. N. Ray (Mukteswar), Dr. M. L. Roonwall (Dehra Dun), Prof. B. R. Seshachar (Bangalore), Prof. R. V. Seshaiya (Annamalainagar), Dr. S. B. Setna (Bombay), Lieut.-Colonel R. B. Seymour Sewell (Cambridge), Miss N. G. Sproston (Shanghai), Dr. B. Sundara Raj (Lucknow), Dr. Viswanath (Hoshiarpur), Dr. G. S. Thapar (Lucknow), and Dr. A. Wolsky (Delhi).

\section{University of Adelaide}

AN announcement has been made inviting applica. tions for twenty-eight new terching posts, including chairs of philosophy, mathematics and physics, at the University of Adelaide. The size and resources of this University, which has always played a leading part in Australian science and thought and has produced an unusual number of persons now outstanding in British scholarship, have already expanded considerably since the end of the War. The further development which is now projected is the result of the decision of the Government of South Australia to make a substantial increase in its University vote, following representations by the vicechancellor, Mr. A. P. Rowe, who was appointed in 1947. It is intended that the new appointments (for which applications close in London with the Association of Universities of the British Commonwealth on January 31) should make possible not only the extension into new fields of the University's teaching and research activities, but also a liberal provision of overseas study-leave for all members of the staff and a reversion to pre-war conditions in the matter of reasonable freedom from teaching duties for research.

\section{University of London : Appointments}

THE following appointments in the University of London have been announced : Dr. E. H. F. Baldwin, to the University chair of biochemistry tenable at University College from January 1; Prof. H. E. M. Barlow, professor of electrical engineering at University College, to the Pender chair of electrical engineering tenable at the College from October 1, 1950, in succession to Prof. R. O. Kapp, who will be retiring at the end of the session 1949-50. The title of professor of chemistry in the University has been conferred on Dr. Kathleen Lonsdale in respect of the post held by her at University College; and the title of professor of aeronautical engineering in the University on Dr. N. A. V. Piercy, in respect of the post held by him at Queen Mary College.

\section{Announcements}

THE University of Leeds has recently received an anonymous gift of $£ 40,000$ towards the cost of the rayon technology building, and also the following grants : $\$ 5,000$ to Prof. W. T. Astbury from the Nuffield Foundation for fundamental investigations on rheumatoid arthritis ; $£ 2,000$, spread over two years, to the Department of Biomolecular Structure from the International Wool Secretariat ; and $£ 1,432$ from the Royal Society for research in the Physics Department.

IN the article on "Acoustics of Rooms" in Nature of December 24, p. 1080, reference is made to various bodies having contributed towards the cost of Dr. R. H. Bolt's visit to Britain to give the lectures which the article describes. Mr. Joseph Emberton, chartered architect, points out that he is not connected with Electrical Musical Instruments, Ltd., and made a gift purely on his own account.

FURTHER details in connexion with the second Oil Shale and Cannel Coal Conference of the Institute of Petroleum have recently been announced (see Nature, August 6, 1949, p. 216). The dates of the Conference are July 4-6, and it will take place at the Royal Technical College, Glasgow. The Conference will open with the James Young Centenary Lecture, and this will be given by Prof. W. M. Cumming. Further details can be obtained from the Secretary of the Institute of Petroleum, 26 Portland Place, London, W.1. 